\title{
International ECOpreneurship: Environmental commitment and international partner selection of Finnish firms from the energy sector
}

\author{
Tamara Galkina ${ }^{1}$ (D)
}

Accepted: 18 February 2021 / Published online: 31 March 2021

(c) The Author(s) 2021

\begin{abstract}
Although numerous scholars recognize that entrepreneurial firms and their environmental innovations play a key role in global environmental progress, the topic of ecopreneurial internationalization has received only scant research attention. This article explores how the environmental commitment of ecopreneurs influences partner selection during the internationalization of their ventures. It does so by following a multiple-case study strategy and examining ecopreneurial small- and medium-size firms from Finland's energy sector. The study proposes that, depending on a dominating type of environmental commitment-affective, continuance, or normativethese ventures should favor partner-related and task-related criteria in different ways when selecting international partners. This article contributes to ecopreneurship and to the literature on partner selection in international entrepreneurship.
\end{abstract}

\section{Resumen}

Aunque numerosos investigadores reconocen que las compañías emprendedoras y sus innovaciones medioambientales juegan un papel determinante en la mejora y el progreso global del medio ambiente, la temática de la internacionalización ecoemprendedora sólo ha recibido hasta la fecha una escasa atención investigadora. Este artículo explora cómo el compromiso medioambiental de los eco-emprendedores influye en la selección del socio/s durante la internacionalización de sus empresas. Ello se lleva a cabo mediante el seguimiento de una estrategia de estudio de casos múltiples de pequeñas y medianas empresas eco-emprendedoras del sector energético en Finlandia. El estudio propone que, dependiendo del tipo dominante de compromiso medioambiental -afectivo, de continuidad o normativo- tales empresas deberían favorecer ciertos criterios relacionados con el socio y con la tarea de diferentes maneras a la hora de seleccionar sus socios internacionales. El artículo contribuye así tanto al

Tamara Galkina

tamara.galkina@uva.fi

1 School of Marketing and Communication, University of Vaasa, PL 700, 65101 Vaasa, Finland 
ámbito del eco-emprendimiento como a la literatura sobre selección del socio en el campo del Emprendimiento Internacional.

Keywords Ecopreneurship · Environmental commitment · International entrepreneurship $\cdot$ Partner selection $\cdot$ SMEs

\section{Summary highlights}

Contributions: This article presents new insights into international entrepreneurship (IE) by examining whether the internationalization of ecopreneurial firms has distinctive characteristics. It proposes that, depending on a dominating type of environmental commitment-affective, continuance, or normative-these ventures should favor partner-related and task-related criteria in different ways when selecting international partners. Hence, this study adds to the existing research on international partner selection in IE. Also, this research contributes to the emerging area of ecopreneurship (or environmental entrepreneurship) by empirically exploring the concept of environmental commitment in the international context.

Research questions/purpose: The aim of this article is to explore the influence of the environmental commitment of ecopreneurs on partner selection during the internationalization of their ventures.

Information/data: This study follows a multiple-case study strategy and examines ecopreneurial small- and medium-size firms from Finland's energy sector through conducting semi-structured interviews.

Results/findings: This article shows that ecopreneurs with dominating affective and continuance environmental commitments are likely to prioritize partner-related criteria when selecting international partners for their ventures, whereas ecopreneurs with a dominating normative environmental commitment are likely to prioritize task-related criteria when selecting international partners for their ventures.

Limitations: This study focuses on ecopreneurial firms from Finland, which can limit generalization of the findings.

Theoretical implications and recommendations: This study offers new insights for IE scholarship by looking at the internationalization of a specific type of SME, namely ecopreneurial ventures. Also, it provides the micro-perspective of individual ecopreneurs who base their networking and international partner selection on their emotions, environmental values, experiences, and commitments. This microlevel analysis has been largely neglected in IE. Additionally, this work contributes to emerging research on ecopreneurship by addressing environmental commitment, an ethical component of green start-ups. Specifically, this article responds to calls to add understanding to the process of ecopreneurship and the decision-making of ecopreneurs, revealing the influences behind an ecopreneur's decisions on international partnership. In addition, by bringing the phenomenon of ecopreneurship 
into the international context, it establishes the missing link between greening and internationalization.

Managerial and practical implications and recommendations: By recognizing different types of environmental commitment, practitioners can estimate what criteria their counterparts will be likely to follow when selecting international partners.

Public policy implications and recommendations: Policy makers are encouraged to create adequate and favorable environmental standards and guidelines for businesses, which, in turn, would allow them to select the most suitable international partners.

Recommendations for further research: The findings from this study can be used in future studies on environmental reputation and how environmental values and norms spread through international business partnership and networking.

\section{Introduction}

Environmental degradation and increasing concerns about its impacts have led many enterprises to adapt sustainable business models, accepting eco standards and incorporating "green" values into their agenda. More and more new ventures base their entire businesses on tackling various environmental challenges; this trend has resulted in a separate research stream of ecopreneurship (Galkina and Hultman 2016; Santini 2017; Dudun et al. 2019). Strong environmental orientation and commitment are the very features that distinguish ecopreneurial firms from other new ventures (Galkina and Hultman 2016). This commitment relates to the entrepreneurs' emotional attachment to environmental concerns and the obligation they feel to be involved in sustainable business practices (Keogh and Polonsky 1998; AntolinLopez et al. 2014). This environmental commitment has substantial effect on various business aspects including management, leadership, and innovations of firms (see, e.g., Nair and Ndubisi 2015); however, little is known how it affects internationalization of ecopreneurial firms.

Overall, research on internationalization of ecopreneurial firms is scarce (Zolfaghari et al. 2019; Terán-Yépez et al. 2020). Existing studies predominantly deal with large and established multinational companies (Aguilera-Caracuel et al. 2012) and do not consider small and medium enterprises (SMEs) that are different in both internationalization (Oviatt and McDougall 2005) and green practices (Bianchi and Noci 1998; Hillary 2000; Biondi et al. 2002; Aykol and Leonidou 2014). Generally, some scholars find that the transfer of environmental management practices to host countries is problematic because it requires higher adaptation costs (King and Shaver 2001; Rugman and Verbeke 2005). Others demonstrate that proactive environmental strategies have positive results, offering additional competitive advantages (Ambec and Lanoie 2008) and potentially fostering internationalization (Dowell et al. 2000; Christmann 2004). Although numerous scholars recognize that ecopreneurial firms and their eco innovations play a key role in global environmental progress and the transition to more environmentally sustainable business paradigms (Isaak 1998; 
Gibbs 2009; Schaper 2010), surprisingly, there has been only scant research on the internationalization of ecopreneurial SMEs (Martín-Tapia et al. 2010; Kirkwood and Walton 2010c). Hence, it remains unclear whether they internationalize in different ways when compared to other SMEs. Particularly, Zolfaghari et al. (2019) demonstrate that ecopreneurs' formal and informal network relation with international partners is an essential factor affecting foreign expansion of their businesses. However, how they network and select international partners is still unexplored. Stemming from this research deficiency, the aim of this article is to explore the influence of the environmental commitment of ecopreneurs on partner selection during the internationalization of their ventures.

By addressing this question, this paper intends to make several important contributions. First, it presents new insights into international entrepreneurship (IE) by examining whether the internationalization of ecopreneurial firms differs from that of other SMEs. Also, it adds to the existing research on international partner selection in IE. Varis et al. (2005) have encouraged more research on this topic because the choice of an appropriate and compatible partner has been almost taken for granted in the extant literature. Second, this research intends to contribute to the emerging area of ecopreneurship (or environmental entrepreneurship) by empirically exploring the concept of environmental commitment in the international context.

\section{Theoretical antecedents}

\section{Ecopreneurship}

Ecopreneurship research emerged more than two decades ago at the intersection of studies on entrepreneurship and environmental policies (Blue 1990; Bennett 1991; Anderson 1998). As a study area, it is still emerging and fragmented (Santini 2017; Dudun et al. 2019), which can be explained by the tremendous variety of disciplines from which it developed, such as political economics, political geography, sociology, business ethics, urban studies, environmental policy studies, and tourism research (Antolin-Lopez et al. 2014; Galkina and Hultman 2016). Ecopreneurship is often seen as a sub-stream of sustainable entrepreneurship (Schaltegger 2002; Dean and McMullen 2007; Parrish 2010) and relates to venturing activity that includes environmental awareness (Gibbs 2009). Similarly, Schaper (2002) identifies ecopreneurship as a separate type of venturing activity associated with environmentally responsible business practices and values. Thompson et al. (2011: p. 222) stipulate that "it investigates how environmentally relevant institutions influence entrepreneurial action by examining how individuals recognize, exploit, and create economic growth while simultaneously creating environmental benefits." Isaak (1998: p. 88) defines ecopreneurs as "social activists, who aspire to restructure the corporate culture and social relations of their business sector though proactive, 
ecologically oriented business strategies." ${ }^{1}$ Overall, ecopreneurship has two, often conflicting, aims: to gain economic profit from an identified opportunity and to achieve positive environmental externality (Volery 2002; Libecap 2009; Kirkwood and Walton 2010a; Pacheco et al. 2010).

In their search for differences from traditional entrepreneurship and drivers of green venturing, scholars offered several typologies of ecopreneurs (Linnanen 2002; Walley and Taylor 2002). The most renown of them is the one suggested by Isaak (2002), who distinguishes between green and green-green ventures. The former relates to conventional enterprises that employ environmental business practices after their establishment, for example, due to changes in market demands, consumer preferences, or industry regulations, and which did not have ecological values in their initial business idea. The latter type describes new ventures that from their inception have environmental values and goals throughout their entire business concept; often, the founders of these firms are ardent environmentalists and their green values are projected onto their creations. With a similar logic, Pastakia (1998) derives two types of ecopreneurs. Thus, commercial ecopreneurs have profit maximization as their primary goal, while social ecopreneurs are driven by a desire to offer environmentally friendly products and transform industries, so that they adopt more environmentally sustainable models. Overall, the logic behind this categorization points to the importance of a strong ethical and normative component that is the essence of ecopreneurship. Therefore, ecoprenuers' special attitudes and traits such as green values, environmental ethics, and passion towards sustainability have been recognized as their discrete characteristic (Renfors 2020; Kirkwood and Walton 2014). These particular qualities turn the discussion to the topic of environmental commitment.

\section{Environmental commitment}

Many researchers have made an effort to examine the aggregate of environmental concerns, experiences, green values, awareness about ecological problems, and feeling of obligations to resolve them. For example, Kuckertz and Wagner (2010) call it sustainability orientation and argue that it determines what ecopreneurs will perceive as market imperfection and what opportunities they will detect; hence, they show that a sustainable orientation positively affects entrepreneurial intention. Other scholars like Schick et al. (2002) suggest a similar term ecological orientation to describe this high level of environmental consciousness and show that it influences every aspect behind the establishment of eco-dedicated firms. Moreover, this orientation can be so strong that it remains the integral part of business, even though entrepreneurs know it may impose additional costs and limit entrepreneurial growth. Antolin-Lopez et al. (2014) conclude that environmental orientation is a prior driver and antecedent of green ventures and that it explains the tension between working towards economic and environmental goals, which constitutes the core dilemma for ecopreneurs.

\footnotetext{
1 See Kirkwood and Walton (2014) for the discussion about the definition of ecopreneurs.
} 
Finding explanations for the distinctive traits of ecopreneurs, Keogh and Polonsky (1998) build on studies about organizational commitment. Assuming that organizations can be committed to various moral philosophies, they offer the concept of environmental commitment, which relates to a rational or emotional attachment to the environment and a sense of obligation to consider the best interests of the environment when conducting business. Environmental commitment may arise internally, from the personal aspirations of the founders and strategic managerial considerations but also externally as a result of regulatory and market pressures. The authors indicate that this commitment can have four dimensions. Hence, depending on the combinations and intensity of environmental commitment, an entrepreneurial orientation to start a green business and behave in a way that supports a sustainable environment will be different (p. 43):

1 Affective commitment relates to "deep personal desires, efforts, underlying beliefs, emotional attachments, and identification with the importance of the natural environment to society and business." Ecopreneurs driven by this internal commitment tend to develop all and any environmental opportunities and spend as much energy as possible achieving their environmental goals;

2 Continuance commitment is based on "desires, efforts, and beliefs predicated almost exclusively on the economic and social costs associated with disregarding the environment." Ecopreneurs with this type of environmental commitment express it by establishing an organizational policy for the environment that guides opportunity identification. The dominant motivation behind this environmental commitment is external stakeholder pressure and "need" to be green.

3 Normative commitment relates to "desires, efforts, and beliefs limited to a sense of obligation - doing only what one is obliged to do for the environment." Ecopreneurs possessing this commitment define opportunities based on satisfying the obligation of "debt." Their "greenness" is defined by the mandatory eco regulations and industry standards that they have to follow. Their businesses qualify as green but the motive to start them can be primarily profit. Therefore, additional "green" opportunities that may result in additional costs to their existing normative agenda may be overlooked or treated as not financially worthwhile.

Emphasizing the difference between these types of environmental commitment, Nair and Ndubisi (2015: p. 167) argue that "managers with affective environmental commitment will stay the cause because they want to, those with continuance environmental commitment because they need to, and those with normative environmental commitment because they ought to." In addition, the strength and nature of the environmental commitment of individual managers may depend on very personal characteristics like their religious beliefs (Cui et al. 2015; Abdelzaher and Abdelzaher 2015) or value systems (Stead and Stead 2000).

According to Nair and Ndubisi (2015) and Jansson et al. (2015), having environmentally committed managers has an influence on the environmental orientation of an entire firm, resulting in pro-environmental strategies, green leadership, and green innovations. Interestingly, continuance and normative types influence an 
organization's environmental practices more than affective types (Nair and Menon 2008). The environmental practices, in turn, lead to increased performance because they help to increase revenues or reduce costs through, for example, better access to certain markets, using pollution control technology and paying less charges, decreasing the cost of materials and energy, etc. (Ambec and Lanoie 2008).

Having a strong environmental performance as well as ecological strategies affects a firm's relationships with various partners (Stead and Stead 2000). Such firms are likely to have more trustworthy relationships with other stakeholders (firms, government, local communities, etc.) and reduce risks associated with these relations (Ambec and Lanoie 2008). Furthermore, they often have a strong environmental reputation, are more attractive to investors (Hussainey and Salama 2010), and are perceived as more reliable partners in strategic alliances (Norheim-Hansen 2015). Altogether, network relationships are crucial for ecopreneurial SMEs because they serve as knowledge pools for their eco innovations (van Kleef and Roome 2007) and help to overcome barriers and liabilities associated with their size and greenness (Lewis et al. 2015). Overall, environmental commitments and reputation are recognized as an essential characteristic of ecopreneurial firms; however, little is known about how they influence their expansion to foreign markets. In the next section, this article will discuss existing research on ecopreneurial internationalization.

\section{Ecopreneurial internationalization}

Ecopreneurship studies still need more insights into how green ventures can grow successfully without diminishing their eco philosophy and reducing their environmental commitments (Holt 2012; Kearins and Collins 2012; Antolin-Lopez et al. 2014). This compromise becomes even more challenging in the context of international expansion, which can be complicated by differences in environmental regulations, the incompatibilities of eco standards, and discrepancies in what is regarded as ecological and environmentally friendly. Thus, together with conventional barriers, such as the liabilities of newness and smallness, a lack of resources and knowledge about foreign markets, the internationalization of SME ecopreneurial firms can be highly problematic due to their self-imposed standards. However, current research lacks an understanding of the link between the greening of businesses and their internationalization (Chiarvesio et al. 2014), though this theme is gaining more research attention.

For example, the study by Martín-Tapia et al. (2010) shows that proactive environmental strategies positively affect the export intensity of SMEs. However, this effect decreases with the size of firms; the smaller the firms, the smaller the effect. In microfirms, environmental strategies are less likely to influence their internationalization than they would in medium-size companies. Loane et al. (2015) provide a typology of the growth trajectories of ecopreneurial firms and show the intensity of their internationalization starting from purely domestic firms to born globals and born-again globals. A more recent study by Zolfaghari and Rialp (2016) looks at the internationalization of SMEs in the Spanish renewable energy industry. Due to a high sensitivity to policy and industry-related trends, they emphasize the external institutional and 
regulatory factors influencing this process and do not consider the specific characteristics of entrepreneurs. In their later study, they look closer to the individual characteristics of international ecopreneurs (Zolfaghari et al., 2019); they show that not only knowledge about the industry and foreign markets, formal and informal ties, education, and international experience but also inner values and affective desire to make the world a better place influence internationalization of their businesses. In this regard, the study by Kirkwood and Walton (2010b) is important because it demonstrates how the green values of ecopreneurs influence their international engagement in supply chain management; for instance, they can be in favor of manufacturing locally despite high costs and also have more local sales due to the high environmental costs of exporting. Hence, ecopreneurs have specific approaches to networking and selecting partners. Next section will discuss the existing research on this topic.

\section{International partner selection and the network approach in IE}

The network approach is one of the most developed foundations of IE (Jones et al. 2011; Peiris et al. 2012; Gray and Farminer 2014). Blankenburg Holm (1995) argue that while the traditional view on internationalization mainly focuses on entry mode selection and entry decision-making, from the network perspective, firms select entry nodes or the "establishment points in a foreign market network" that connect expanding firms with customers and suppliers (Jansson and Sandberg 2008: p. 67). Therefore, a firm's resources are more a matter of inter-firm interactions than intrafirm characteristics (Hadley and Wilson 2003). From the network view, business expansion abroad is seen as a process that is influenced by all managerial levels and involves numerous actors from both inside and outside a firm network; therefore, expansion abroad is a cumulative, interactive, and unpredictable process of the constant reconsideration of actions and adaptation among network actors under everchanging conditions. Holm et al. (1996) emphasize two main features of the network perspective on business exchange relations. First, they cannot be deterministic because they can be developed and sustained only when both parties are interested. Second, the informal component is a significant feature of business relations. Hence, network development is a complex, uncertain, and time-consuming process of multilateral interaction (Axelsson and Johanson 1992; Johanson and Vahlne 2003).

The increasing importance of network relationships during internationalization can be demonstrated by the major changes in one of the most influential theoretical foundations of international business - the Uppsala internationalization process model (Johanson and Vahlne 1977). While the original model shows that companies tend to internationalize gradually, starting with countries of close psychic proximity and then progressing towards more distant markets, the revisited Uppsala model replaces the concepts of psychic distance and the liability of foreignness with network position and the liability of outsidership (Johanson and Vahlne 2009). Hence, the barriers to internationalization are no longer associated with country borders but relate to insider or outsider positions within foreign business networks.

The networking process primarily occurs at the inter-personal level and involves emotional components and feelings of dislike, sympathy, attractiveness, and/or trust. 
Therefore, personal traits of entrepreneurs are important in networking and partner selection. Often, they add a non-rational and non-goal-driven decision-making to the internationalization of SMEs (Ellis 2000; Ellis and Pecotich 2001; Meyer and Skak 2002; Galkina and Chetty 2015).

Networking during internationalization implies an iterative process of international partner selection. However, research on networks in IE and research on international partner selection have remained somewhat isolated from each other. Perhaps, this separation has happened because the topic of partner selection was initially studied in the broader context of large and established enterprises. It has also been studied in the context of international joint ventures (Glaister and Buckley 1997), franchising (Wang and Altinay 2008; Doherty 2009), and, more generally, in international strategic alliances (Li and Ferreira 2008). Notably, many of these studies are based on the earlier work by Geringer (1991), who argues that decisions on international partner selection are based on two groups of criteria. First, task-related criteria referring to the operational skills and resources needed to achieve the goals of partnership; they can include human resources, financial resources, patents, access to marketing channels, physical premises, knowledge of local markets and local culture. Second, partner-related criteria refer to the past history of the relationships between firms, trust between top management teams, reputation, a partner's corporate and national culture, the ethical aspects of a partner's business, etc.

For instance, the study by Al-Khalifa and Peterson (1999) demonstrates that taskrelated criteria are important in decisions to engage in a joint venture, while partnerrelated criteria dominate in decisions on the implementation of the joint venture. Significantly, partner-related criteria like corporate history and the personal characteristics of CEOs have been ranked higher in their importance. Dong and Glaister (2006) examine international strategic alliances from the perspective of Chinese firms; they find that task-related selection criteria are specific to an alliance and are strongly determined by the strategic motives for their formation. The partner-related selection criteria are more general in nature; thus, they are less influenced by strategic motives. A later study by Islam et al. (2011) adds the variable of the size of a firm to Geringer's criteria. They show that when choosing partners for international joint ventures, large and medium enterprises place a greater emphasis on task-related criteria, while small firms find partner-related criteria are more important. They also find that firms with little international experience will value partner-related criteria more, while firms with extensive international experience will focus on task-related criteria. Besides the abovementioned research, Geringer's criteria have been used by many other studies on international partnering by firms of various age and size (Glaister and Buckley 1997; Tatoglu and Glaister 2000; Varis et al. 2005) and are also relevant for this article.

\section{Methodology}

This research follows the qualitative course and applies a multiple-case study strategy. There are several reasons that explain this methodological choice. First, this study focuses on the concepts of environmental commitment and business partnering 
that deal closely with the emotions, motives, and values of ecopreneurs. These individual behavioral characteristics require a special focus on their personal interpretations and the context that a case study method allows researchers to capture. Second, this research is exploratory in nature and does not aim to verify any testable hypotheses and the case study method is particularly suited to answering open and inductive research questions (Patton 1990; Yin 2004; Pratt 2009). Third, the methodology of a study should fit the state of development in the field where the study is conducted. According to Edmondson and McManus (2007), a qualitative case study-based research with open-ended questions is more appropriate within emerging and uninvestigated areas, like ecopreneurship. In addition, the previous research has shown that the most appropriate way to explore ecopreneurship is as an understudied phenomenon (see, e.g., Isaak 1998; Linnanen 2002; de Bruin and Lewis 2010).

Replication logic and purposeful sampling were employed to select the case companies, meaning that they were selected for a specific reason and have had a special significance for the study (Yin 2004; Stake 1995). The criteria for selecting the case firms were (a) environmental commitment; (b) SMEs with less than 250 employees, which is the SME definition of the European Union (European Commission 2003: p. 5); (3) international operations; and (d) a willingness to participate in the research. After examining the internet profiles of several potential companies, 12 firms were approached during an annual industry event called EnergyWeek in Vaasa, Finland. Through informal personal conversations, the author of this article invited them to participate in this study, with six of them agreeing. The profiles of these selected firms are presented in Appendix Table 1.

Semi-structured interviews were the appropriate technique for the data collection. In total, 21 interviews were conducted with the founders and managers of the selected firms. Each interview lasted between 45 and 90 min and was recorded, and later transcribed. The informants were aware they were being recorded. Those who wanted to know the questions before the interview received them via e-mail, together with a general description of the project.

In addition to interviews providing the primary data sources, secondary sources were also employed. As suggested by Cassell and Symon (1994), the author of this article used the firms' websites, industry-associated websites, and other available press releases to prepare for interviews and further verify general information about the individuals to be interviewed, the history of their ventures, their core businesses and products, and their main clients and suppliers. Thus, data triangulation (Yin 2004) was achieved by comparing information obtained during the interviews with information from the secondary sources. To ensure the accuracy of the collected information, the interview transcripts were sent back to the interviewees for additional verification. Also, to avoid misinterpretations, some interviewees were contacted by e-mail to clarify and specify certain details. Furthermore, the findings from this study were exposed to questioning and criticism when presented at both industry and academic seminars and conferences.

The informal analysis of the data started already during the interviews when, for example, formulating questions based on recently received answers. The formal analysis included both manual and electronic techniques. Thus, following the techniques described by Miles and Huberman (1994), the patterns in the data were found 
by analyzing the manual data, which includes within-case and cross-case displays, field notes, matrices, and tables. The themes identified in the literature, e.g., networks, environmental values, environmental commitment, emotions about environmental concerns, partner selection, were matched with the data and further refined with reference to them. The electronic data analysis included analysis by the NVivo software application. The results of this analysis are presented in the next section.

\section{Findings from the cases and discussion}

In line with research in IE (see, e.g., Meyer and Skak 2002; Johanson and Vahlne 2009; Galkina and Chetty 2015), the internationalization of the selected ecopreneurial ventures was found to be relationship-dependent and network-driven. Similar to the studies by van Kleef and Roome (2007) and Lewis et al. (2015), networks were highly important for these SMEs because they used relationships for obtaining various types of resources, for example, information about new markets, knowledge about products, and financial and legal support in the host countries. The quote below is very illustrative of this finding:

Founder of F6: "When our company started to grow internationally, networks became a pool of opportunities. We received a lot of offers from people who wanted to do business with us. One Italian guy came directly to me saying that he has an idea to develop a wind power plant in Albania. He had good connections there because his wife was Albanian. So, we started to exchange ideas, and documents. Then we decided to move to Albania and establish a company there. Something similar happened in West Africa, in Senegal. A guy came to me and said that he had an opportunity in Senegal to develop a solar plant there. He had good local contacts there and knew important people. I went there, I saw the place and saw the local people. I met local people that are now our partners. I liked them and we decided to start the company".

In terms of resources obtained from networks for internationalization, the studied firms did not differ from other SMEs. However, the way they networked and selected international partners was influenced by the environmental commitment of the founders. Below, I will address how this international partner selection was influenced by the three types of environmental commitment.

\section{Affective environmental commitment and international partner selection}

Regarding the six studied firms, F4 and F5 were the ones that had most strongly expressed the affective environmental commitment that is deeply inherent in the values and beliefs of a company founder and which are then spread throughout the company (Keogh and Polonsky 1998). This strong emotional reaction to environmental issues and the desire to resolve them by means of entrepreneurial activities can be illustrated by the following quote: 
Founder \#1 of F5: "I am an entrepreneur, but first of all I am a regular person who believes in certain things. I am personally very environmentally oriented. I am vegetarian because, you know, meat production is one of the biggest contributors to green-house gases; I cycle to work whenever possible instead of using a car. I try to teach my kids to love nature, to reduce the amount of waste our family produces... I love clothes from GlobeHope; you know that shop in Helsinki - they make really fancy things from recycled materials. I want to do what I preach. It is not only about business; it is my lifestyle! Instead of waiting for someone to change this world, I want to create that change! Or at least a small step to that big change. So, all this naturally becomes a part of what I am doing as an entrepreneur... And I think we are alike in our team, we wanted to keep it as part of our business. Later on it became a part of our mission and vision that we communicated that to the rest of the business community."

This prevailing affective environmental commitment has influenced the way F4 and F5 selected its international partners and international networking activities in general. Like in the proverb "Birds of a feather flock together," the founders of F4 and F5 favored similar environmental orientations in their partners and tried to network with like-minded entrepreneurs. This can be seen in the following interview excerpt:

Founder \#1 of F5: "When I network, I first see a person and then all the business behind him. So, reputation and trust are the priority. If this is a new partner, I ask someone who knows him or her better to tell me something about them. Naturally we select partners from similar industries, and this business is full of people who think like we think... I mean have similar environmental concerns and ideas to solve them. So, in that sense, it is not hard to find them... we're from one pool, we attend the same events."

Founder \#2 of F4: "Yes, we try to select similar partners... but it's the business world, and as a small firm you do not always have a luxury to select, so there are trade-offs... But firms are not faceless; there are people behind them... so for me this 'human' side is more important than say the 'functional' side [...] So, for me it does not matter if we grow slowly; growth and speed are not a priority. It is more important to work with 'the right' people. And finally as a business owner I can choose who to work with [...] I mean, usually these things go together; if someone has a good green reputation and is a trustworthy and reliable partner, then most probably this firm is good in other aspects too."

As suggested by Ambec and Lanoie (2008) and Hussainey and Salama (2010), partners that affectively shared similar views towards environmental concerns were perceived as more reliable and attractive. Their reputation and orientation towards more ecological practices was an important characteristic, which resonates with Kuckertz and Wagner (2010) and Schick et al. (2002). The evidence shows that the 
founders of F5 pay close attention to personality and partner-related criteria (Geringer 1991) when selecting international partners. Hence, the first proposition can be offered:

P1: Ecopreneurs with a dominating affective environmental commitment are likely to prioritize partner-related criteria and, in particular, their environmental reputation when selecting international partners for their ventures.

\section{Continuance environmental commitment and international partner selection}

In the data set, founders F2 and F6 provide examples of having a dominant continuance environmental commitment. Thus, the firms needed to be green in order to stay competitive, while presenting their best practices to other stakeholders. In addition, F6, for example, had a rather strong environmental policy and culture within the organization, which facilitated environmental values in the business. The quote below provides examples of this interpretation:

Founder \#10f F6: "Our company spent a lot of money to spread our 'green' values both inside and to other companies. We did it through the traditional channels of marketing and communication. We attended exhibitions, had articles in newspapers and magazines and used blogging in social networks. We also tried to educate the members of our network (clients and other business partners). In our building we have a seminar room, and we organized different training sessions and meetings with, for example, professors from universities. Our company is a bit different from other companies because we always try to spread knowledge about renewable energy and its importance to the environment. We need to show it [environmental commitment] to our partners in order to be ahead... We invested a lot of money into these information meetings. It is difficult to measure if it was successful or not, but we liked it. It was also important for motivating employees and for our brand."

Founder \#2 of F6: "Fossil energy resources are like an old school. Renewable energy is a new school. It is like autocracy and democracy. And there is a confrontation between them. Fossil energy is an established industry, and people want to keep it like that. They don't want anyone new there. But renewable energy and 'green' energy is becoming cheaper and more available - it is a developing industry. And we need to spend a lot of energy educating our partners and clients to make them understand that it is the future."

This continuance environmental commitment affected the way F2 and F6 selected international partners. The quotes below demonstrate that they primarily favored partner-related criteria (Geringer 1991) and, like F4 and F5, tried to network with similar green firms:

Former CEO and current CTO of F2: "This green energy industry is very small and peculiar in terms of players. Everyone knows everyone. So, hav- 
ing an eco-status and the image of a clean and reliable partner is important. Because of this pressure, we can't partner with whoever. We need to be careful. So, we check how green our suppliers are, [...] to the extent we can do it. Their reputation is very important for us. Because later we will be judged based on who we partner with."

Founder \# 1of F6: "Our partners are green not only because our firm has green products and we're in this environmentally-responsible sector. It is also a matter of our own reputation. We're young and small and cannot afford to have suspicious partners in our network. For our future, we need to be careful [...] so, we want to see that they [partners] are reliable and have a good reputation."

The emphasis on eco-status and importance of partners' reputation as reliable environmentally responsible members of the network was an essential criterion for selecting them when expanding to foreign markets, which corresponds with MartínTapia et al. (2010) and Zolfaghari et al. (2019). Based on the above observations, this article states the following proposition:

P2: Ecopreneurs with a dominating continuance environmental commitment are likely to prioritize partner-related criteria and, in particular, their environmental reputation when selecting international partners for their ventures.

\section{Normative environmental commitment and international partner selection}

Two firms from the data set, F1 and F3, provided examples of normative environmental commitment. They positioned themselves as eco businesses and qualified as one. However, their commitment to environmental values was determined by external regulations and industry trends. Their environmental impact was more of a side effect than an initial value. This can be seen in the illustrative quotes below:

Founder \#1 of F1: "I don't think I bring my personal environmental values into our company... I mean, I try to be a good citizen, I separate garbage and so on... But I don't think it really affects our business. Green things sell nowadays, maybe it is a trend... So, it is good to have a product that is environmentally friendly and sustainable. Yes, our firm is positioned as a 'green' business in the environmental sector. But this 'greenness' is a side effect. It is a result of optimization. I don't think we're purely a green business - we're in the business of harvesting energy, meaning that we provide solutions for not consuming energy unnecessarily."

Founder \#2 of F1: "Basically, we help to save energy and not to produce it more. So, yes, we help to decrease $\mathrm{CO}_{2}$ emissions; in this regard we're in the eco-sector. But, this ecological effect is more like a context already, taken for granted... It is the benefit that comes along. But our initial idea was saving... not spending money to buy external energy."

Founder \#1 of F3: "When you come to a potential investor and say that you want to save the planet, most probably you won't get money for this altruistic talk. But if you show in real numbers how much one can save with the help of our device, our control system and the sensor, then the chances are greater... 
I don't think we have strong environmental values in our team... We're committed [to our business] because we like what we do, it's fun and we can make a good living with it. But if it helps to save our environment, it's great! I am proud of that small effect for the environment... but we didn't start from that idea,"

The dominating normative environmental commitment of ecopreneurs from F1 and F3 affected the way they chose network partners for their businesses. Unlike the previous cases, their own environmental reputation and the green image of their potential partners were secondary criteria for them. The quotes below illustrate that they mainly considered task-specific criteria (Geringer 1991) when selecting international partners:

Founder \#1 of F1: "We don't start asking our potential partners about their environmental values. No. I guess this is because it is not in our own minds. I think we look at their general reliability. Patents are important for us [...] and also experiences in local markets."

Founder \#2 of F3: "We have recently established a partnership with one company in Europe; they will sell and install our sensors. The most important thing for us was their established position in the local market and their knowledge of local customers. Also, it is quite a big player, so we hope we can get to other companies through them."

Basing on such findings, the next proposition is:

P3: Ecopreneurs with a dominating normative environmental commitment are likely to prioritize task-related criteria when selecting international partners for their ventures.

In addition, the data show that for ecopreneurs with dominating affective commitment and continuance environmental commitment, the process of networking and international partner selection also became a process for spreading environmental values and concerns to other partners. For ecopreneurs with a dominating affective environmental commitment (F4 and F5), whose environmental values were so organically inherent in their businesses, it was a natural process triggered internally. For ecopreneurs with a dominating continuance environmental commitment (F2 and F6), it was more of a deliberate process triggered by external pressures from stakeholders. They arranged different events, seminars, and forums in order to change existing attitudes towards energy solutions and the environment in general. Regarding F6, the founders even talked about educating their business partners and raising their environmental awareness. Hence, by spreading environmental values and norms, they tried to change industry standards of doing business. These findings show that networking and partner selection are examples of concrete business practices that establish a direct link between entrepreneurial personality, ethics, and value systems on the micro-level and instigate change towards more sustainable business models on the macro-level. 


\section{Contributions and directions for further research}

This study demonstrates the importance of network relationships for international ecopreneurial firms, which is consistent with the received literature in IE (Johanson and Vahlne 2009; Jones, Coviello and Tang 2011). However, in the context of new green ventures with environmental commitments, it provides new insights on how they choose who to network with. The results show that ecopreneurial ventures with different types of environmental commitment tend to favor partner-related and taskrelated criteria differently when selecting international partners. The present study suggests several important contributions that can trigger further research.

First, this study offers new insights for IE scholarship by looking at the internationalization of a specific type of SME, namely ecopreneurial ventures. Studies in this direction have been very scarce and fragmented (Zolfaghari et al. 2019), while published studies mainly point to the internationalization barriers associated with differences in regulations and business logic (e.g., Steinz et al. 2015), which are not unique to ecopreneurial SMEs. However, this study shows the distinctiveness of ecopreneurial SMEs in terms of establishing partnerships during internationalization. The focus on environmental commitment - as a part of entrepreneurial identity - and partnerships with international entrepreneurs, who embrace additional social objectives (like environmental sustainability), presents the IE phenomenon from a novel angle. This article provides the micro-perspective of individual ecopreneurs who base their actions on their emotions, value systems, experiences, and commitments. This micro-level analysis has been largely neglected in IE; therefore, this study responds to the calls to understand the process of creating international green ventures (Zolfaghari et al. 2019) and moves the IE domain forward (Zucchella 2021). The article also adds to the international partner selection literature in IE. It shows how the system of the entrepreneurs' personality, their ethical values, and environmental concerns influence the selection of partners.

Extending these results further, researchers can look deeper into the topics of environmental reputation and its influence on international partner selection. Could some firm serve as an ecological role model for other firms in network relationships? How do firms create and legitimate their "green" image for other partners and authorities both domestically and on international arenas? Does this image influence their partner selection? Exploring these topics would suggest important contributions can be made to the social capital literature and that on international partner selection in IE. In addition, some of the cases (see, for example, F5) show that the compatibility of partners can be a question of trade-offs between the environmental commitments of ecopreneurs and the economic goals of their firms. This finding can be extended to the area of positive organizational psychology (see, e.g., Wright 2003; Donaldson and Ko 2010); scholars could also explore whether these trade-offs result in cognitive dissonance in ecopreneurs and how it affects their well-being.

Second, this study also contributes to emerging research on ecopreneurship by addressing environmental commitment, an ethical component of green start-ups. Specifically, this article responds to calls to add understanding to the process of ecopreneurship and the decision-making of ecopreneurs (Antolin-Lopez et al. 2014), 
revealing the influences behind an ecopreneur's decisions on international partnership. In addition, by bringing the phenomenon of ecopreneurship into the international context, it establishes the missing link between greening and internationalization (Chiarvesio et al. 2014). Taking these findings further, scholars may explore the process of spreading environmental values and norms through international business partnership and networking. Examining the topic in such a way would allow ecopreneurship to be seen from the perspective of being a social movement (Jenkins 1983; Buechler 1995) and help to provide a deeper understanding of ecopreneurs as social activists, innovators, and transformation agents that move societies towards a more sustainable paradigm. Ultimately, it would advance the whole emerging research area of ecopreneurship.

\section{Appendix}

Table 1 Profiles of the case firms selected for the study

\begin{tabular}{|c|c|c|c|c|}
\hline Firm & Area of business & $\begin{array}{l}\text { Number of } \\
\text { employees }\end{array}$ & $\begin{array}{l}\text { Year of } \\
\text { inception }\end{array}$ & International markets \\
\hline F1 & $\begin{array}{l}\text { Solar energy devices and photo- } \\
\text { voltaic solutions }\end{array}$ & 3 & 2013 & Germany, Russia \\
\hline $\mathrm{F} 2$ & $\begin{array}{l}\text { Wind turbine power plant solu- } \\
\text { tions }\end{array}$ & 15 & 2008 & China \\
\hline F3 & $\begin{array}{l}\text { Lightning and energy-saving } \\
\text { solutions }\end{array}$ & 3 & 2014 & Spain, Germany \\
\hline $\mathrm{F} 4$ & Energy storage systems & 2 & 2014 & $\begin{array}{l}\text { Estonia, Sweden, China, } \\
\text { Russia }\end{array}$ \\
\hline F5 & $\begin{array}{l}\text { Energy-saving technology and } \\
\text { solutions }\end{array}$ & 5 & 2013 & $\begin{array}{l}\text { USA, Poland, Czech Republic, } \\
\text { Ukraine }\end{array}$ \\
\hline F6 & $\begin{array}{l}\text { Installation of photo voltage } \\
\text { plants, solar energy }\end{array}$ & 12 & 2010 & Italy, Albania, Senegal \\
\hline
\end{tabular}

Funding Open access funding provided by University of Vaasa (UVA).

\section{Declarations}

Ethics approval and consent to participate All procedures performed in this study involving human participants were in accordance with the ethical standards of the institutional and/or national research committee and with the 1964 Helsinki declaration and its later amendments or comparable ethical standards.

Informed consent Informed consent was obtained from all individual participants included in the study.

Conflict of interest The author declares no competing interests.

Open Access This article is licensed under a Creative Commons Attribution 4.0 International License, which permits use, sharing, adaptation, distribution and reproduction in any medium or format, as long as 
you give appropriate credit to the original author(s) and the source, provide a link to the Creative Commons licence, and indicate if changes were made. The images or other third party material in this article are included in the article's Creative Commons licence, unless indicated otherwise in a credit line to the material. If material is not included in the article's Creative Commons licence and your intended use is not permitted by statutory regulation or exceeds the permitted use, you will need to obtain permission directly from the copyright holder. To view a copy of this licence, visit http://creativecommons.org/licen ses/by/4.0/.

\section{References}

Abdelzaher D, Abdelzaher A (2015) Beyond environmental regulations: exploring the potential of "EcoIslam" in boosting environmental ethics within SMEs in Arab markets. J Bus Ethics. https://doi.org/ 10.1007/s10551-015-2833-8

Aguilera-Caracuel J, Hurtado-Torres NE, Aragón-Correa JA (2012) Does international experience help firms to be green? A knowledge-based view of how international experience and organisational learning influence proactive environmental strategies. Int Bus Rev 21:847-861

Al-Khalifa A, Peterson SE (1999) The partner selection process in international joint ventures. Eur J Mark 33(11/12):1064-1081

Ambec S, Lanoie P (2008) Does it pay to be green? A systematic overview. Acad Manag Perspect 22(4):45-62

Anderson AR (1998) Cultivating the garden of Eden: environmental entrepreneuring. J Organ Chang Manag 11(2):135-144

Antolin-Lopez R, Martínez-del-Rio J, Céspedes-Lorente JJ (2014) Environmental entrepreneurship: a review of the current conversation after two decades of research. Paper presented at 2014 GRONEN Conference, Helsinki, Finland

Axelsson B, Johanson J (1992) Foreign market entry - the textbook vs. the network view. In: Axelsson B, Easton G (eds) Industrial networks. A new view of reality. Routledge, London, pp 218-234

Aykol B, Leonidou LC (2014) Researching the green practices of smaller service firms: a theoretical, methodological, and empirical assessment. J Small Bus Manag 53(4):1264-1288

Bennett SJ (1991) Eco-preneuring: the complete guide to small business opportunities from the environmental revolution. Wiley, New York

Bianchi R, Noci G (1998) Greening SMEs competitiveness. Small Bus Econ 11:269-281

Biondi V, Iraldo F, Meredith S (2002) Achieving sustainability through environmental innovation: the role of SMEs. Int J Technol Manag 24:612-626

Blankenburg Holm D (1995) A network approach to foreign market entry. In: Möller K, Wilson D (eds) Business marketing: an interaction and network perspective. Kluwer Academic Publications, New York

Blue J (1990) Ecopreneuring: managing for results. Scott Foresman, London

Buechler SM (1995) New social movement theories. Sociol Q 36(3):441-464

Cassell C, Symon G (1994) Qualitative research in work contexts. In: Cassell C, Symon G (eds) Qualitative methods in organizational research: practical guide. SAGE, London, pp 1-13

Chiarvesio M, De Marchi V, Di Maria E (2014) Environmental innovations and internationalization: theory and practices. Bus Strateg Environ. https://doi.org/10.1002/bse.1846

Christmann P (2004) Multinational companies and the natural environment: determinants of global environmental policy standardization. Acad Manag J 47(5):747-760

Cui J, Jo H, Velasquez MG (2015) The influence of Christian religiosity on managerial decisions concerning environment. J Bus Ethics 132:203-231

De Bruin A, Lewis K (2010) Little acorns in action: green entrepreneurship and New Zealand microentrepreneurs. In: Schaper M (ed) Making ecopreneurs: developing sustainable entrepreneurship, 2nd edn. Gower Applied Business Research, Surrey, pp 95-107

Dean TJ, McMullen JS (2007) Towards a theory of sustainable entrepreneurship: reducing environmental degradation through entrepreneurial action. J Bus Ventur 22:50-76

Doherty AM (2009) Market and partner selection process in international retail franchising. J Bus Res 62(5):528-534 
Donaldson SI, Ko I (2010) Positive organizational psychology, behavior, and scholarship: a review of an emerging literature and evidence base. J Posit Psychol 5(3):177-191

Dong L, Glaister K (2006) Motives and partner selection criteria in international strategic alliances: perspective of Chinese firms. Int Bus Rev 15(6):577-600

Dowell G, Hart S, Yeung B (2000) Do corporate global environmental standards create or destroy market value? Manag Sci 46(8):1059-1074

Dudun M, Ivashchenko N, Gurinovich A, Tolmachev O, Sonina L (2019) Environmental entrepreneurship: characteristics of organization and development. Entrepreneurship Sustain Issues 6(4):1861-1870

Edmondson AC, McManus SE (2007) Methodological fit in management field research. Acad Manag Rev 32(4):1155-1179

Ellis P (2000) Social ties and foreign market entry. J Int Bus Stud 31(3):443-469

Ellis P, Pecotich A (2001) Social factors influencing export initiations in small and medium-sized enterprises. J Mark Res 38(1):119-130

European Commission (2003) The new SME definition: user guide and model declaration. http://ec. europa.eu/enterprise/policies/sme/files/sme_definition/sme_user_guide_en.pdf. Accessed 15 Jan 2021

Galkina T, Chetty S (2015) Effectuation and networking of internationalizing SMEs. Manag Int Rev. https://doi.org/10.1007/s11575-015-0251-x

Galkina T, Hultman M (2016) Ecopreneurship: assessing the field and outlining research potential. Small Enterp Res forthcoming. https://doi.org/10.1080/13215906.2016.11887162016.1188716

Geringer JM (1991) Strategic determinants of partner selection criteria in international joint ventures. J Int Bus Stud 22(1):41-62

Gibbs D (2009) Sustainable entrepreneurs, ecopreneurs and the development of sustainable economy. Greener Manag Int 55:63-78

Glaister K, Buckley P (1997) Task-related and partner-related selection criteria in UK international joint ventures. Br J Manag 8(3):19-36

Gray B, Farminer A (2014) And no birds sing- reviving the romance with international entrepreneurship. J Int Entrep 12:115-128

Hadley RD, Wilson HIM (2003) The network model of internationalization and experiential knowledge. Int Bus Rev 12(6):697-717

Hillary R (2000) Small and medium-sized enterprises and the environment. Greenleaf, Sheffield

Holm D, Ericksson K, Johanson J (1996) Business networks and cooperation in international business relationships. J Int Bus Stud 27(5):1033-1053

Holt D (2012) The journey of a 'green' micro-enterprise: the green planet. Corp Soc Responsib Environ Manag 19(2):90-101

Hussainey K, Salama A (2010) The importance of corporate environmental reputation to investors. J Appl Acc Res 11(3):229-241

Isaak R (1998) Green logic: ecopreneurship, theory and ethics. Greenleaf Publishing, Sheffield

Isaak R (2002) The making of the ecopreneur. Greener ManagInt 38:81-91

Islam S, Ali MY, Sandhu MS (2011) Partner selection criteria in international joint ventures: perspective of foreign investors from Asian NIEs of Malaysia and India. Asia Pac Bus Rev 17(1):25-43

Jansson H, Sandberg S (2008) Internationalization of small and medium sized enterprises in the Baltic Sea Region. J Int Manag 14(1):65-77

Jansson J, Nilsson J, Modig F, Hed Vall G (2015) Commitment to sustainability in small and medium sized enterprises: the influence of strategic orientation and management values. Bus Strateg Environ. https:// doi.org/10.1002/bse.1901

Jenkins JC (1983) Resource mobilization theory and the study of social movements. Ann Rev Sociol 9:527-553

Johanson J, Vahlne J-E (1977) The internationalization process of the firm: a model of knowledge development and increasing foreign market commitments. J Int Bus Stud 8(1):23-32

Johanson J, Vahlne J-E (2003) Business relationship learning and commitment in the internationalization process. J Int Entrep 1(1):83-101

Johanson J, Vahlne J-E (2009) The Uppsala internationalization process model revisited: from liability of foreignness to liability of outsidership. J Int Bus Stud 40(9):1411-1431

Jones M, Coviello N, Tang YK (2011) International entrepreneurship research (1989-2009): a domain ontology and thematic analysis. J Bus Ventur 26(6):632-659 
Kearins K, Collins E (2012) Making sense of ecopreneurs' decisions to sell up. Bus Strateg Environ 21(2):71-85

Keogh PD, Polonsky MJ (1998) Environmental commitment: a basis for environmental entrepreneurship? J Organ Chang Manag 11(1):38-49

King AA, Shaver JM (2001) Are aliens green? Assessing foreign establishments' environmental conduct in the United States. Strateg Manag J 22(11):1069-1086

Kirkwood J, Walton S (2010a) What motivates ecopreneurs to start business? Int J Entrep Behav Res 16(3):204-228

Kirkwood J, Walton S (2010b) Howecopreneurs' green values affect their international engagement in supply chain management. J Int Entrep. https://doi.org/10.1007/s10843-010-0056-8

Kirkwood J, Walton S (2010c) What motivates ecopreneurs to start businesses? Int J Entrepreneurial Behav Res 16(3):204-228

Kirkwood J, Walton S (2014) How green is green? Ecopreneurs balancing environmental concerns and business goals. Aust J Environ Manag 21(1):37-51

Kuckertz A, Wagner M (2010) The influence of sustainability orientation on entrepreneurial intentions: investigating the role of business experience. J Bus Ventur 25(5):524-539

Lewis KL, Cassells S, Roxas H (2015) SMEs and the potential for a collaborative path to environmental responsibility. Bus Strateg Environ 24(8):750-764

Li D, Ferreira MP (2008) Partner selection for international strategic alliances in emerging economies. Scand J Manag 24(4):308-319

Libecap G (ed) (2009) Frontiers of eco entrepreneurship research. Emerald, Bingley

Linnanen L (2002) An insider's experience with environmental entrepreneurship. Greener Manag Int 38:71-80

Loane S, Galkina T, Ramsey E (2015) Ecoprenuerial internationalisation: is it, far away fields or the green, green grass of home? Paper presented at the AIB UKI conference, Manchester

Martín-Tapia I, Aragón-Carrea JA, Reuda-Manzanares A (2010) Environmental strategy and export in medium, small and micro-enterprises. J World Bus 45:266-275

Meyer K, Skak A (2002) Networks, serendipity, and SME entry to Eastern Europe. Eur Manag J 20(2):179-188

Miles MB, Huberman AM (1994) Qualitative data analysis: an expanded source book, 2nd edn. SAGE, Thousand Oaks

Nair SR, Menon CG (2008) An environmental marketing system - a proposed model based on Indian experience. Bus Strateg Environ 17(8):467-479

Nair SR, Ndubisi NO (2015) Evaluating management's environmental commitment and link with firm's environmental orientation. J Manag Res 15(3):165-178

Norheim-Hansen A (2015) Are 'green brides' more attractive? An empirical examination of how prospective partners' environmental reputation affects trust-based mechanism in alliance formation. J Bus Ethics 132:813-830

Oviatt BM, McDougall PP (2005) Defining international entrepreneurship and modeling the speed of internationalization. Entrep Theory Pract 29(5):537-553

Pacheco DF, Dean T, Payne D (2010) Escaping the green prison: entrepreneurship and the creation of opportunities for sustainable development. J Bus Ventur 25:464-480

Parrish BD (2010) Sustainability-driven entrepreneurship: principles of organization design. J Bus Ventur 25(5):510-523

Pastakia A (1998) Grassroots ecopreneurs: change agents for a sustainable society. J Organ Chang Manag 11(2):157-173

Patton MQ (1990) Qualitative evaluation and research methods. SAGE, Thousand Oaks

Peiris I, Akoorie MEM, Sinha P (2012) International entrepreneurship: a critical analysis of studies in the past two decades and future direction for research. J Int Entrep 10:279-324

Pratt MG (2009) For the lack of boilerplate: tips on writing (and reviewing) qualitative research. Acad Manag J 52(5):856-862

Renfors S-M (2020) Identification of ecopreneurs' business competencies for training program development. J Educ Bus 95(1):1-9

Rugman AM, Verbeke A (2005) Towards a theory of regional multinationals: a transaction cost economics approach. Manag Int Rev 45:5-17

Santini C (2017) Ecopreneurship and ecopreneurs: limits, trends and characteristics. Sustainability 9(4):492. https://doi.org/10.3390/su9040492 
Schaltegger S (2002) A framework for ecopreneurship: leading bioneers and environmental managers to ecopreneurship. Greener Manag Int 38:45-58

Schaper M (2002) The essence of ecopreneurship. Greener Manag Int 38:26-30

Schaper M (2010) Making ecopreneurs: developing sustainable entrepreneurship, 2nd edn. Gower Applied Business Research, Surrey

Schick H, Marksen S, Freimann J (2002) Sustainability issues for start-up entrepreneurs. Greener Manag Int 38:59-71

Stake RE (1995) The art of case study research. SAGE, Thousand Oaks

Stead JG, Stead E (2000) Eco-enterprise strategy: standing for sustainability. J Bus Ethics 24:313-329

Steinz HJ, Van Rijnsoever FJ, Nauta F (2015) How to green the red dragon: a start-ups' little helper for sustainable development in China. Bus Strateg Environ. https://doi.org/10.1002/bse.1899

Tatoglu E, Glaister K (2000) Strategic motives and partner selection criteria in international joint ventures in Turkey: perspectives of Western firms and Turkish firms. J Glob Mark 13(3):53-93

Terán-Yépez E, Marín-Carrillo GM, Casado-Belmonte M, Capobianco-Uriarte M (2020) Sustainable entrepreneurship: Review of its evolution and new trends. J Clean Prod 252. https://doi.org/10.1016/j.jclep ro.2019.119742

Thompson N, Kiefer K, York J (2011) Distinctions not dichotomies: exploring social, sustainable and environmental entrepreneurship. Advances in Entrepreneurship, Firm Emergence and Growth 13:205-233

van Kleef JAG, Roome NJ (2007) Developing capabilities and competence for sustainable business management as innovation: a research agenda. J Clean Prod 15:38-51

Varis J, Kuivalainen O, Saarenketo S (2005) Partner selection for international marketing and distribution in corporate new venture. J Int Entrep 3(1):19-36

Volery T (2002) Ecopreneurship: rationale, current issues and future challenges. In: Figlisteraller U, Pietner HJ, Volery T, Weber W (eds) Radical change in the world: will SMEs soar or rash? KMU Verlag, St. Gallen, pp 541-553

Walley EE, Taylor D (2002) Opportunists, champions, mavericks...? A typology of green entrepreneurs. Greener Manag Int 38:31-43

Wang C, Altinay L (2008) International franchise partner selection and chain performance through the lens of organizational learning. Serv Ind J 28(2):225-238

Wright TA (2003) Positive organizational behavior: an idea whose time has truly come. J Organ Behav 24:437-442

Yin R (2004) The case study anthology. SAGE, Thousand Oaks

Zolfaghari M, Rialp A (2016) International entrepreneurship in emerging industry: the case of renewable energy industry in Spain. Paper presented at the Academy of International Business annual meeting, New Orleans, USA

Zolfaghari M, Manesh E, Rialp A (2019) International ecopreneurs: the case of eco-entrepreneurial new ventures in the renewable energy industry. J IntEntrep 17:103-126

Zucchella A (2021) International entrepreneurship and the internationalization phenomenon: taking stock, looking ahead. Int Bus Rev. https://doi.org/10.1016/j.ibusrev.2021.101800

Publisher's Note Springer Nature remains neutral with regard to jurisdictional claims in published maps and institutional affiliations. 